\title{
MEMOLES KEMAMPUAN MENGAJAR GURU SOSIOLOGI
}

\section{Oleh: Junaidi}

\section{A. Latar belakang}

Tidak bisa dipungkiri bahwa dalam beberapa dekade terakhir kualitas pendidikan Indonesia mengalami stagnan. Bila negara lain pendidikannya senantiasa bergerak dari titik rendah ke titik-titik tinggi beikutnya, Indonesia hanya bergerak di satu titik saja. Akibtanya, output (lulusan) pendidikan Indonesia sulit memberikan hal yang terbaik dalam persaingan global tenaga dan sumber daya manusia.

Menyadari persoalan di atas, pemerintah lantas berusaha mengembalikan kualitas pendidikan Indonesia dengan mengeluarkan berbagai kebijakan, yaitu antara lain merenovasi kurikulum. Saat ini sedang diterapkan Kurikulum Tingkat Satuan Pendidikan (KTSP), yang sementara ini diyakini sebagai kurikulum terbaik. Kemudian, pemerintah juga mengupayakan peningkatan kemampuan guru dengan memberikan kesempatan belajar ke jenjang yang lebih tinggi lagi. Malah sekarang ini para guru "diwajibkan” untuk berpendidikan minimal starat 1 (sarjana).

Satu di antara kebijakan itu yakni peningkatan pendidikan guru dinilai sangat tepat, sebab guru merupakan pihak terdepan yang berhadapan dengan siswa atau peserta didik dalam proses pembelajaran di sekolah. Guru adalah titik sentral dan punya peran strategis meningkatkan kualitas pendidikan melalui pembelajaran di sekolah. 
Sosiologi sebagai sebuah mata pelajaran dalam kurikulum perlu mendapatkan perhatian. Mata pelajaran ini dimaksudkan untuk memberikan kompetensi kepada peserta didik dalam memahami konsep-konsep seperti sosialisasi, kelompok sosial, perubahan sosial, lembaga sosial, konflik sosial serta integrasi sosial, dan lain-lain. Selain memberikan peserta didik dengan pengetahuan, sosiologi juga memiliki misi menjadikan peserta didik mempunyai sikap dan perilaku yang sesuai dengan nilai dan norma-norma yang berlaku dalam masyarakat.

Dengan demikian, pelajaran sosiologi bukan hanya ditujukan pada sisi teoritis berupa pemberian pengetahuan dan pemahaman rasional tentang individu, masyarakat dan kebudayaan sebagai sebuah sistem, tetapi juga memberikan kemampuan praktis kepada peserta didik dalam mengembangkan keterapilan sikap dan perilaku yang resional dan kritis dalam menghadapi kemajemukan masyarakat, kebudayaan, situasi sosial, serta masalah sosial yang banyak terjadi dalam kehidupan masyarakat. Kemampuan ini bisa diumpamakan seperti dokter medis yang mampu mendiagnosis penyakit pasien dan dapat menentukan obatnya, maka demikian pula kemampuan yang harus dimiliki oleh peseta didik, dia adalah dokter sosial yang mampu mendiagnosis penyakit dan berbagai masalah kemasyarakatan serta mampu merumuskan terapi atau solusinya.

Berdasarkan hal di atas, maka seorang guru sosiologi adalah orang yang memiliki kemampuan yang kompleks dan sekaligus memiliki keterampilan yang mumpuni dalam membelajarkan peserta didik sehingga tujuan mata pelajaran 
sosiologi dapat tercapai seoptimal mungkin. Kenyataannya hingga saat ini kita masih menjumpai guru sosiologi yang belum "upgrade" kemampuannya. Akibatnya muncullah beberapa persoalan dalam pembelajaran sosiologi terhadap perseta didik seperti mereka tidak begitu tertarik belajar sosiologi, pemahaman konsep-konsep sosiologi yang minim dan sebagainya, sehingga bermuara pada rendahnya hasil belajar.

Makalah sederhana ini berusaha membahasa proses pembelajaran sosiologi yang menyangkut kemampuan guru dalam menyampaikan materi. Pemilihan judul dengan menggunakan kata memoles didasarkan pada pemikiran bahwa pada hakekatnya gugur-guru sosiologi sudah memiliki kemampuan dasar sebagai seorang pengajar sehingga mereka tidak perlu diajarkan dengan hal-hal yang pokok dan universal. Selain itu secara sadar maupun tidak setiap manusia termasuk guru pasti memiliki konsep-konsep langsung pada dirinya tentang materi sosiologi. Makalah ini dimaksudkan untuk mengingatkan para guru sosiologi untuk meningkatkan kemampuan menyampaikan materi dengan memanfaat hal-hal yang telah ada pada diri peserta didik dan diri guru sendiri.

\section{B. Beberapa Persoalan Kemampuan Mengajar Guru Sosiologi}

Persoalan kemampuan mengajar guru sosiologi maksudnya adalah kemampuan atau keterampilan yang harus dilakukan oleh sorang guru dalam proses pembelajaran sesuai dengan tuntutan dan tujuan KTSP, yakni 
pembelajaran yang sesuai dengan karakteristik masing-masing daerah dan karakteristik peserta didik. KTSP menuntut guru untuk mengkontekstualkan atau menghubungkan materi dengan lingkungan peerta didik dan realitas di sekitarnya. Dalam prakteknya keterampilan tersebut tidak terlaksanakan sebagaimana mestinya oleh guru. Keterampilan itu antara lain adalah (a) mengaitkan materi dengan pengetahuan lain yang relevan, (b) melaksanakan pembelejaran yang kontekstual, (c) melaksanakan pembelajaran yang memungkinkan tumbuhnya kebiasaan posisitf( (nurturant effect).

Selain dari tiga hal di atas juga ditemukan kelemahan guru dalam memberikan materi Prkatek Penelitian baik dalam penyajian teoritis maupun dalamm praktek pelaksanaannya. Kelemahan berikutnya adalah guru hanya bergantung pada satu atau dua buku sumber saja.

1. Melaksanakan pembelajaran yang kontekstual

Maksud melaksanakan pembelajaran yang kontekstual adalah guru dituntut memberikan informasi atau materi pelajaran dengan contoh-contoh kejadian nyata pada masyarakat atau lingkungan dimana peserta didik tersebut berada, atau dengan peristiwa nyata yang tengah menjadi perbincangan orang bayak saat itu. Sebagai contoh kita ambil lagi KD menganalisis penyebab konflik dalam masyarakat. Untuk siswa di Kota Padang, guru bisa mengkontekskannya dengan konflik yang terjadi antara aparat polisis pamong praja (Satpol PP) dengan para pedagang kaki lima, atau konlflik dalam penempatan pedagang Pasar raya antara pihak pemerintah kota dengan para pedangang Pasar Raya 
Padang. Bagi guru yang berada di daerah bisa mengkontekskannya dengan konflik sosial yang terjadi di daerah yang bersangkutan, misal daerah Pasaman Barat dan Pesisir Selatan terjadi konflik antara warga masyarakat dengan investor atau perusahaan sawit.

Dalam skala yang sederhana dan langsung bersentuhan dengan peserta didik materi tentang penyebab konflik sosial bisa juga dikontekastualkan, misal fenomena yang banyak dialami oleh para orang tua karena anaknya susah untuk diajak belajar lantaran pengaruh internet dan playstation (PS) yang begitu kuat. Beberapa orang tua mengeluh akan hal ini. Kejadian nyata ini bisa dikontekstualkan oleh guru, sebab keberadaan internet dan PS bisa ditemui di perkotaan maupun di daerah (pedesaan).

2. Kemampuan mengaitkan materi dengan pengetahuan lain yang relevan

KTSP menuntut guru sosiologi (ini berlaku untuk semua bidang studi) mengembangkan materi dengan mengaitkannya dengan pengetahuan lain. Dalam proses pembelajaran guru sangat terpaku pada kompetensi dasar (KD), indikator, dan tujuan pembelajaran yang sudah ditetapkan dalam rancangan pelaksanaan pembelajaran (RPP). Salah satu contoh adalah kompetansi dasar menganalisis faktor penyebab konflik dalam masyarakat. Ketika memberikan materi tersebut guru tidak bisa beranjak dari KD, indikator, dan tujuan pembelajaran yang sudah ditetapkan.

Masalah di atas sebetulnya bisa dihindari apabila guru memiliki pemahaman yang dalam tentang hakikat konflik. Materi tentang konflik sosial 
(begitu juga materi-materi lainnya) sangat bisa dikaitkan dengan pengetahuan lain, sebab materi konflik sosial sangat banyak berkaitan dengan aspek atau pengetahuan lain, misal dengan aspek ekonomi. Dengan aspek ekonomi guru bisa menginformasikan kepada peserta didik bahwa konflik sosial disebabkan oleh kemiskinan. Selanjutnya kemiskinan disebabkan oleh kebijakan ekonomi pemerintah yang tidak jelas arahnya atau kebijakan yang tidak pro pada rakyat bawah. Dari sisi hukum konflik sosial juga bisa dikaitkan, yakni disebabkan oleh pelanggaran warga terhadap norma-norma yang sudah berlaku dalam kelompok masyarakat. Begitu pun dari aspek-aspek lainnya, materi konflik sosial bisa dikaitkan oleh guru sosiologi.

3. Melaksanakan pemeblejaran yang memungkinkan tumbuhnya kebiasaan positif (nurturant effect)

Pembelajaran yang memungkinkan tumbuhnya kebiasaan posisitf adalah refleksi materi terhadap sikap dan perilaku peserta didik setelah mempelajari materi tersebut. Pada hakekatnya setiap materi memungkinkan tumbuhnya kebiasaan positif.

Sama halnya dengan dua hal di atas, dalam proses pembelajaran sosiologi, guru hampir tidak pernah merefleksikan materi ke arah pembentukan sikap, kebiasaan atau perilaku positif peserta didik. Padahal sebetulnya setiap guru bisa melakukannya, contoh KD menganalisis penyebab konflik dalam masyarakat, yang materi mengkaji tentang penyebab dan akibat yang ditimbukan karena konflik. Berdasarkan kejadian nyata di Kota Padang peserta 
didik dengan dibantu guru bisa menganalisis penyebab dan sekaligus akibat konflik dari konflik antara Pemko Padang dengan para pedagang. Salah satu akibatnya adalah kerugian berupa hilang atau berkurangnya mata pencaharian pedagang. Begitu pula dengan konflik sosial dalam masyarakat antara orang tua dengan anak. Akibat internet atau PS prestasi belajar anak jadi menurun.

Berkaca dari dua contoh akibat konflik tersebut guru bisa memberikan nasehat atau masukan kepada peserta didik agar mereka bisa menjauhkan sikap dan perilaku yang dapat menyebabkan atau memicu terjadinya konflik. Refleksi ini sejatinya dilakukan guru terhadap semua materi sosiologi.

\section{Kemampuan mengajarkan materi Praktek Penelitian}

Salah satu materi pokok yang terdapat dalam KTSP Sosiologi SMA dan Madrasah Alian (MA) adalah Praktek Penelitian. Materi ini diberikan untuk satu semester pada kelas 3 (XII), tepatnya di semester terakhir. Rasionalitas penempatan materi ini di semester akhir adalah atas dasar anggapan bahwa peserta didik sudah memiliki cukup banyak pengetahuan sosiologi dan pemahaman mengenai masalah-masalah sosial. Dengan demikian mereka bisa memilih, menetapkan, dan merencanakan apa yang akan diteliti.

Praktekm penelitian mencakup kemampuan membuat perencanaan (proposal) penelitian, pelaksanaan, penelitian, kemampuan menganalisis (mengolah) data, dan menyusun laporan penelitian. Untuk peserta didik level penelitiannya dikategorikan sederhana. Penelitian mereka tentu saja berbeda dengan skripsi mahasiswa. 
Berdasarkan pengamatan pada tugas penelitian peserta didik, ditemui beberapa hal yang harus diperbaiki melalui guru yang mengajarkannya, yaitu (a) judul penelitian yang tidak berbeda dengan judul berita atau tulisan di media massa, (b) tidak adanya latar belakang yang problematis, (c) tidak ada bukti data hasil wawancara atau hasil observasi (yang disuguhkan hanya identitas informan), (d) analisis data hanya berisi teori sederhana, (e) terpisahnya antara teori dengan data hasil penelitian, dan sebagainya.

Kelemahan penelitian peserta didik di atas tidak terlepas dari kemampuan guru yang mengajarkannya. Hal ini diakui oleh beberapa guru yang mengajar praktek penelitian. Mereka mengakui bahwa mereka sendiri tidak terlalu paham bagaimana membuat rancangan penelitian hingga laporan penelitian yang baik. Hal inilah yang menjadi salah satu penyebab guru sosiologi tidak melakukan penelitian, guna memenuhi persyaratan kenaikan golongan dan pangkat.

5. Kemampuan memilih dan menyeleksi buku sumber

Pada umumnya guru sosiologi hanya menghandalkan dan mempercayakan sumber materi pada satu atau dua buku sumber. Mereka selalu menyampaikan materi sesuai dengan yang ada di dalam buku yang minim jumlahnya.

Akibat dari minimnya buku sumber adalah guru tidak bisa menyeleksi mana informasi yng benar dan mana yang tidak, atau mana yang logis dan mana yang tidak. Kadang guru menyampaikan informasi yang tidak benar kepada 
peserta didik. Sebaliknya sebagian peserta didik juga tidak punya perbandingan informasi tentang matei tersebut.

\section{Akar Persoalan dan Solusi}

Melihat persoalan kemampuan pembelajaran guru sosiologi di atas, penulis menyimpulkan bahwa semua itu berakar pada pemilikan sumber belajar yang terbatas dan kurangnya usaha memnfaatkan sumber informasi yang ada seperti surat kabar, TV dan sebagainya. Mereka cenderung tidak menggandrungi acara-acara atau informasi berupa berita, tetapi lebih memilih acara populer dan hiburan.

Proses pembelajaran yang baik menurut para ahli adalah pola belajar inkuiri - ekspositori dan proses berfikir deduktif - induktif. Jika digambarkan proses tersebut adalah sebagai berikut:

Proses belajar : $\quad$ Inkuiri $\longrightarrow$ Ekspositori

Proses berfikir : $\quad$ Deduktif $\longrightarrow$ Induktif

Dalam proses pembelajaran guru menyampaikan atau menuntun peserta didik mengemukakan fakta atau peristiwa-peristiwa nyata di tengah kehidupan masyarakat kepada peserta didik. Setelah itu guru menuntun peserta didik untuk menemukan dan menyimpulkan informasi berdasarkan fakta atau peristiwaperistiwa tersebut. 
Adapun paradigma dan titik sentral pembelajaran adalah terletak pada peserta didik. Pembelajaran dimulai dari inkuiri menuju ekspositori atau dari deduktif menuju induktif. Guru menuntun dan mengarahkan peserta didik untuk "memanfaatkan" informasi-informasi yang mereka miliki dan pengalaman yang mereka alami dalam memahami sebuah materi. Dengan demikian pengetahuan yang diperoleh melalui proses pembelajran seperti itu menjadi bermakna bagi peserta didik.

Proses pembelajaran di atas akan berhasil dengan prasyarat mutlak guru sosiologi mau "menyadari" kekurangan sendiri dan berusaha untuk mengatasinya. Mereka idealnya menanamkan keinginan yang kuat untuk memiliki sumber belsjar sebanyak mungkin dan sekaligus memanfaatkannya.

\section{Penutup}

Upaya peningkatan kualitas pembelajaran sosiologi mutlak dilakukan. Salah satu titik sentral untuk mewujudkan upaya tersebut adalah melalui polesan terhadap kemampuan pembelajaran guru. Guru dituntut untuk memiliki dan memanfaatkan sebanyak mungkin sumber belajar dan sumber informasi. 


\section{DAFTAR PUSTAKA}

Depdiknas. 2003. Standar Kompetensi Mata Pelajaran Untuk SMA dan MA. Jakarta: Balitbang Depdiknas.

E. Mulyasa. 2006. Kurikulum Tingkat satuan Pendidikan. Bandung: Remaja Rosdakarya.

Hamzah B Uno. 2006. Perencanaan Pembelajaran. Jakarta: Bumi Aksara.

Johnson, Elaine B. 2009. Contextual teaching and Learning. Terjemahan Ibnu Setiawan. Bandung: MLC.

Martinis Yamin. 2008. Desain Pembelajaran Berbasis Tingkat Satuan Pendidikan. Jakarta: GP Press.

Trianto. 2010. Model Pembelajaran Terpadu. Jakarta: Bumi Aksara.

Azmi. 2007. Pembelajaran Sosiologi. Makalah.

UU No 20 Tahun 2003 tentang Sistem Pendidikan Nasional.

Permendiknas No 41 Tahun 2007 tentang Standar Proses. 